\title{
Prevalence of urinary schistosomiasis among primary school pupils in Wamakko Local Government, Sokoto State, Nigeria
}

\author{
Imrana Arzika Muhammad ${ }^{1 *}$, Kabiru Abdullahi ${ }^{2}$ Aminu Yabo Bala ${ }^{1}$ and Sa'adatu Aliyu Shinkafi ${ }^{2}$
}

\begin{abstract}
Background: A cross-sectional study was conducted to determine the prevalence of urinary schistosomiasis among primary school pupils in Wamakko Local Government, Sokoto State, Nigeria. Four hundred terminal urine samples were collected from primary school pupils and analysed using standard filtration technique.

Results: Out of the 400 urine samples examined, 192 (48\%) were found to be infected with Schistosoma haematobium. Males had a higher prevalence (49.49\%) than females (43.93\%), although statistical analysis indicated no significant association of $\mathrm{S}$. haematobium infection with gender. The highest infection rate was recorded among pupils aged 4-6years (62.82\%) while the least was found among pupils aged 7-9years; this did not attend significant level $(p>0.05)$. The occurrence of $S$. haematobium infection did not significantly associate with a source of drinking water and water contact activity $(p>0.05)$.

Conclusion: This study indicates the presence of urinary schistosomiasis in the study area and that all pupils in the study area are equally exposed to the source of infection. Therefore, prompt intervention is highly advocated.
\end{abstract}

Keywords: Urinary schistosomiasis, Infection, Filtration technique, Gender, Wamakko, Sokoto

\section{Background}

Schistosomiasis known as bilharziasis or snail fever is a parasitic disease that seriously affects internal organs with the popular symptom being blood in urine and/faeces and an enlarged liver. The disease mostly affects the health of school-age children (Adeyaba \& Ojeaga, 2002). Urinary schistosomiasis is a parasitic infection causing serious inflammatory changes and continues to damage different organs of the body. The infection is acquired through contact with cercaria-polluted water during washing clothes and utensils, swimming, wading or bathing (Akinboye et al., 2011).

More than 66 million people throughout 54 countries in Africa are affected by $S$. haematobium infection (Badmos \& Komolafe, 2007). In S. haematobium infection, the eggs are trapped in tissues and cause progressive damage to the bladder, ureters and kidney. There is dysuria (painful urination) and haematuria (blood in

\footnotetext{
* Correspondence: imranamuhammad40@gmail.com

'Department of Biological Sciences, Usmanu Danfodiyo University, Sokoto, Nigeria

Full list of author information is available at the end of the article
}

urine) (Bello, Jimoh, Shiitu, \& Hudu, 2014). In a study conducted in Nigeria, 26\% of more than 1000 cases of appendicitis were attributed to S. haematobium (Carter Center, 2015).

The disease can present as chronic, which is most common, or acute. Haematuria (blood in urine) and dysuria (painful urination) are the main early symptoms of the disease. For most people who are regularly exposed, the severity of disease depends upon the intensity of infection. Mostly individuals with few schistosome worms, and especially adults, remain asymptomatic, although about $80 \%$ of infected children show early symptoms and signs of disease (Mott, 1983; Olds, 2000). It was estimated that 70 million individuals out of 282 had experienced haematuria and 32 million had dysuria associated with $S$. haematobium infection. It was estimated that 18 million suffer bladder wall pathology and 10 million had hydronephrosis (Van der Werf et al., 2003).

Parasitological diagnosis of $S$. haematobium infection is readily undertaken by urine filtration. While urine is easily collected, due to the circadian pattern of egg excretion, specimens should ideally be collected between 
10:00 am and 2:00 pm and preferably after physical exercise (World Health Organization, 2012). For S. haematobium infection, the presence of micro- or macrohaematuria has enabled the development and validation of a range of indirect diagnostic tests useful for epidemiological mapping of prevalence, such as the dipstick methods which detect micro- and macrohaematuria (Guyatt, Brooker, Lwambo, Siza, \& Bundy, 1999).

In children, schistosomiasis can cause anaemia and physical weakness and consequently reduce their ability to learn, although these negative impacts can be reversed with appropriate treatment. Chronic schistosomiasis may result in death. In sub-Saharan Africa, more than 200,000 deaths per year are caused by the disease (WHO, 2012).

If freshwater contact is unavoidable, bathing water should be heated to $50{ }^{\circ} \mathrm{C}$ for $5 \mathrm{~min}$ or treated with iodine or chlorine as for the treatment of drinking water. Water can also be strained through paper filters, or allowed to stand for 2 to 3 days before use. High waterproof boots or hip waders are recommended if wading through streams or swamps. Vigorous towel drying, and rubbing alcohol on exposed skin immediately after contact with untreated water, may also help reduce cercarial penetration. Vegetables should be well cooked and salads avoided as these may have been washed in infected water, allowing cercariae to attach themselves to the leaves (Robson, 2013).

Minimizing morbidity can be effectively supported through parallel preventive measures, i.e. reducing the contamination of water with schistosome eggs and at the same time preventing exposure of humans to schistosome-infested water (World Health Organization, 2002). Unfortunately, health education, water supply and sanitation programmes have only a marginal impact on the youngsters playing in and around water bodies and on people, whose occupation involves water contact. Therefore, snail control is an important preventive measure in an integrated approach to control schistosomiasis transmission (Madsen \& Christensen, 1992; Sturrock, 2001).

Urinary schistosomiasis poses a public health problem. Despite the intervention, the disease still persists. This study was carried out to determine the prevalence of urinary schistosomiasis among primary school pupils in Wamakko Local Government Sokoto State, Nigeria.

\section{Materials and methods}

\section{Study area}

The study was carried out in Wamakko Local Government Area of Sokoto State, Nigeria, which lies between latitude $12^{\circ} \mathrm{N}$ and $13^{\circ} 58 \mathrm{~N}$ and longitude $04^{\circ} 8^{\prime} \mathrm{E}$ and $6^{\circ}$ $54 \mathrm{E}$ (Fig. 1). Wamakko was estimated to have an area of $697 \mathrm{~km}^{2}$ and a population of 209,204 (National Population
Census, 2015). Wamakko Local Government Area was described by the presence of hills, sandy savannah, in addition to numerous rivers, streams and dams. The annual rainfall is about $50 \mathrm{~mm}$ with the highest peak in August. The predominant tribe in Wamakko is Hausa. The residents were mainly farmers and fishermen (Kabiru et al., 2013).

\section{Study design}

A cross-sectional study was carried out in which urine samples were collected from the pupils and examined to estimate the prevalence of urinary schistosomiasis among primary school pupils in Wamakko Local Government, Sokoto State, Nigeria.

\section{Sample size determination}

The sample size was estimated using the single proportion formula with a confidence interval of $95 \%$ and a precision of $5 \% . N=Z^{2} p q / d^{2}$, where $N=$ sample size to be determined, $Z=$ standard normal deviate at $95 \%$ confidence interval $(=1.96), P=$ proportion of the population estimated to have attributed from the previous study, and this was obtained from the study conducted in Wamakko local Government by Kabiru et al. (2013) where they recorded a prevalence of $38.3 \%$.

\section{Collection of urine samples and parasitological examination}

Each pupil was given a $30-\mathrm{ml}$ sterile wide mouth, screw-capped plastic container carrying their identification number and was instructed on how to collect the urine sample. A total of 400 urine samples were collected between 10:00 am and 14:00 pm. The samples were taken to parasitology Laboratory, Usmanu Danfodiyo University, Sokoto, and were analysed using standard filtration technique as described by Pugh (1978). Questionnaires were administered to the pupils to obtain information on the source of drinking water and water contact activity.

\section{Data analysis}

Data obtained were summarized into tables. Prevalence was calculated using the formula: No. of pupils infected/ (No. of pupils examined) $\times 100$. Chi-square $\left(\chi^{2}\right)$ statistical analysis was used to determine the association of frequency of infection occurrence with schools, class, sex, age, the source of drinking water and water contact activity. $p$ values less than 0.05 were considered significant. Data were analysed using Quantitative Parasitological (QP) Software version 3.0.

\section{Results}

Schistosoma haematobium infection was recorded among primary school pupils in Wamakko Local Government, 


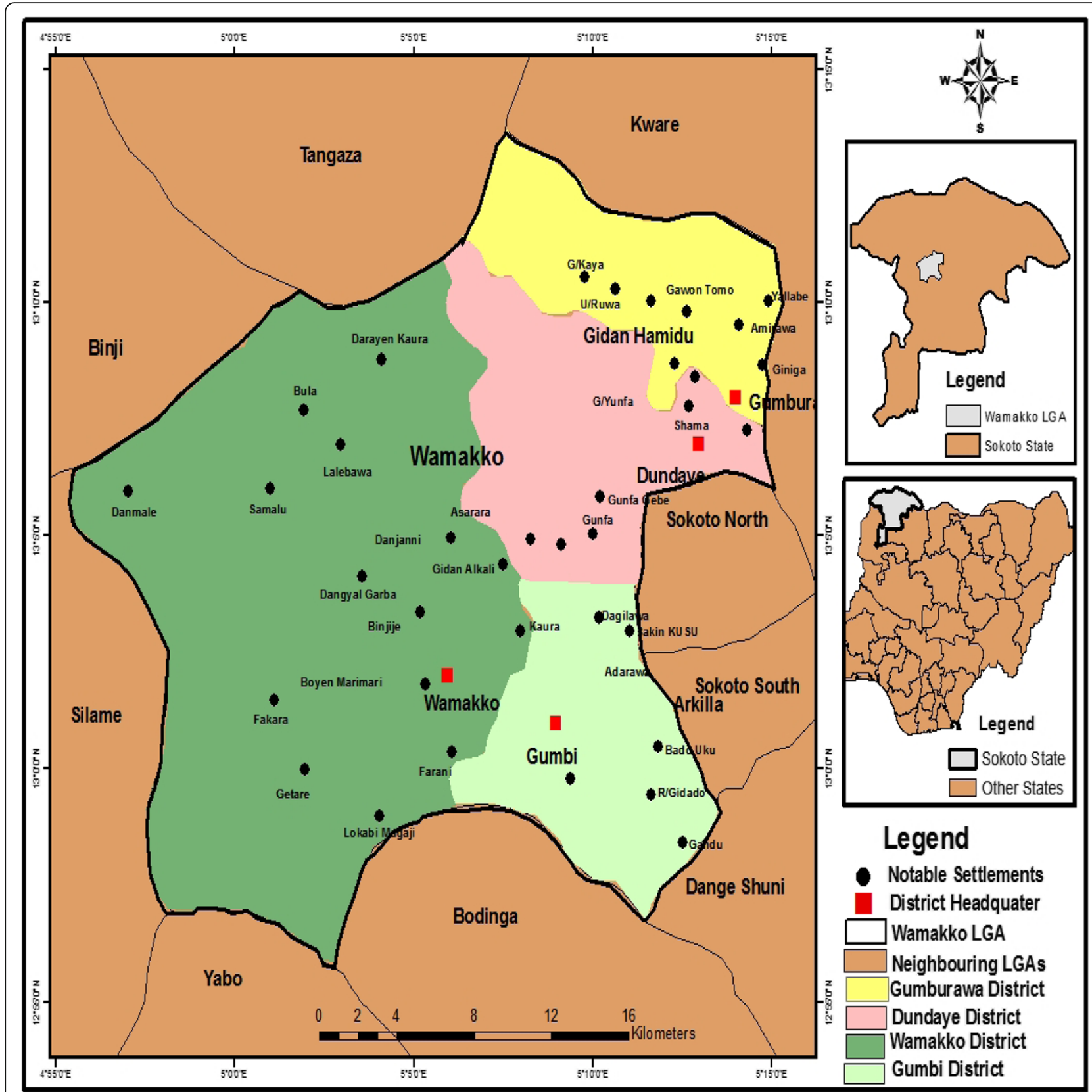

Fig. 1 Map of Nigeria, Sokoto State, and Wamakko Local Government Area showing the four districts

Sokoto State. Out of the 400 samples examined for urinary schistosomiasis, 192 were found to be positive having a prevalence of $48 \%$ and mean egg intensity of 12.02 eggs/ $10 \mathrm{ml}$ of urine. The highest prevalence (57\%) was recorded among pupils from Tangwale primary school while pupils from Kaura Kimba and Gidan Bubu primary schools had the least prevalence (40\% each) (Table 1$)$.

It could be seen from Table 2 that males had a higher prevalence $(49.49 \%)$ than females with a prevalence of $43.93 \%$. The occurrence of S. haematobium did not significantly associate with gender $\left(\chi^{2}=0.972\right.$ : $\mathrm{df}=1, p=0.147)$. Similarly, there was a higher mean egg intensity in males $(14.3 \mathrm{egg} / 10 \mathrm{ml})$ than in $\mathrm{fe}-$ males (4.98 eggs $/ 10 \mathrm{ml})$. However, statistical analysis indicated no significant difference $(p>0.05)$ in the mean egg intensity of the pupils with respect to gender (Table 2).

Pupils aged 4-6years had the highest prevalence of $62.86 \%$, while pupils aged 7-9 years had the least prevalence of $40.67 \%$. Statistical analysis indicated no association between the occurrence of infection and age group $\left(\chi^{2}=8.37: \mathrm{df}=3 p>0.699\right)$. On the other hand, the mean 
Table 1 School and class prevalence of Schistosoma haematobium infection among primary school pupils in Wamakko Local Government Area, Sokoto

\begin{tabular}{|c|c|c|c|c|}
\hline Parameters & No. of pupils examined & No. of pupils infected & Prevalence (\%) & Mean count (eggs/10 ml) \\
\hline \multicolumn{5}{|l|}{ School } \\
\hline Wajeke & 100 & 55 & 55.00 & 8.00 \\
\hline Tangwale & 100 & 57 & 57.00 & 15.18 \\
\hline Kaura Kimba & 100 & 40 & 40.00 & 14.43 \\
\hline Gidan Bubu & 100 & 40 & 40.00 & 10.63 \\
\hline Total & 400 & 192 & 48.00 & 12.02 \\
\hline
\end{tabular}

egg intensity was significantly $(p<0.05)$ highest in pupils aged 13 years and above $(16.19$ eggs $/ 10 \mathrm{ml})$ while pupils aged 4-6 years had the lowest mean egg intensity $(6.50$ eggs/10 ml) (Table 2).

It could be seen from Table 3 that pupils who use the river as their source of drinking water had the highest prevalence (100\%) while pupils who use well recorded the least prevalence (45.51\%). No significant association exists between the occurrence of infection and source of drinking water $\left(\chi^{2}=4.62: \mathrm{df}=2 p>0.265\right)$. The mean egg intensity was the highest among pupils who use well as their source of drinking water $(13.57$ eggs $/ 10 \mathrm{ml})$ while pupils who use river had the least mean egg $(6.50$ eggs $/ 10 \mathrm{ml})$. There is no significant difference $(p>0.05)$ in mean egg intensity with respect to the source of drinking water (Table 3).

The prevalence of $S$. haematobium infection in relation to water contact activity was found to be highest among pupils who visit river to wash (83.33\%) while those who do not know their water contact activity had the least prevalence (37.23\%). Statistical analysis indicated no significant association between the occurrence of $S$. haematobium infection and water contact activity $\left(\chi^{2}=22.6: \mathrm{df}=5 p>0.81\right)$. The mean egg intensity of the infection was the highest among pupils who engage in irrigation farming $(25.88$ eggs $/ 10 \mathrm{ml})$ while those who feed animals and those who fetch water both recorded mean egg intensity $(2.70$ eggs $/ 10 \mathrm{ml})$. Statistical analysis indicated a significant difference $(p<0.05)$ between mean egg intensity of pupils with respect to water contact activity (Table 3 ).

\section{Discussion}

The current study showed the occurrence of S. haematobium infection among primary school pupils in Wamakko Local Government, Sokoto State, Nigeria, with an overall prevalence of $48 \%$. The prevalence of $48 \%$ recorded in this study is higher than $18.7 \%$ reported by Damen, Kopkuk, and Lugos (2018) in North Central Nigeria, 38.3\% reported by Kabiru et al. (2013) in Wamakko Local Government, 37.7\% reported by Bello et al. (2014) in Wurno Local Government all in Sokoto State, and 32.0\% reported by Hassan et al. (2017) in Kebbi State, Northwestern Nigeria. This prevalence reflects the high exposure of the pupils to cercaria-contaminated water bodies.

Findings of this study revealed that $S$. haematobium infection did not significantly associate with gender. This is in conformity with other findings such as that of Kabiru et al. (2013) in Wamakko Local Government, Sokoto State; Dawet, Benjamin, and Yakubu (2012) in Jos North, Plateau State; and Nwachukwu, Ohaeri, Ukpai, Irole-Eze, and Amaechi (2018) in Ebonyi State, Nigeria. This indicates that both sexes are equally exposed to the source of $S$. haematobium infection. However, other authors such as Badmos and Komolafe (2007) in Ibadan, Oyo State; Sarkinfada, Azeez-Akande, Isa, and Zubairu (2009) in Kano State; Joseph, Gaji, Muhammad, Baba, and Thilza (2010) in Maiduguri,

Table 2 Sex and age prevalence of urinary schistosomiasis among primary school pupils in Wamakko Local Government Area, Sokoto

\begin{tabular}{|c|c|c|c|c|}
\hline Parameters & No. of pupils examined & No. pupils infected & Prevalence (\%) & Mean count (eggs/10 ml) \\
\hline \multicolumn{5}{|l|}{ Sex } \\
\hline Males & 293 & 145 & 49.49 & 14.30 \\
\hline Females & 107 & 47 & 43.93 & 4.98 \\
\hline \multicolumn{5}{|l|}{ Ages (years) } \\
\hline $4-6$ years & 35 & 22 & 62.86 & 6.50 \\
\hline 7-9 years & 150 & 61 & 40.67 & 14.43 \\
\hline 10-12 years & 154 & 82 & 53.25 & 10.33 \\
\hline 13 years and above & 61 & 27 & 44.26 & 16.19 \\
\hline Total & 400 & 192 & 48.00 & 12.02 \\
\hline
\end{tabular}


Table 3 Prevalence of Schistosoma haematobium among primary school pupils in Wamakko Local Government Area, Sokoto, in relation to the source of drinking water, water contact activity and painful urination (dysuria)

\begin{tabular}{lllll}
\hline Parameters & No. of pupils examined & No. of pupils infected & Prevalence (\%) & Mean count (eggs/10 ml) \\
\hline Source of drinking water & 2 & & 100 & 6.50 \\
River & 97 & 2 & 54.64 & 8.21 \\
Tap & 301 & 53 & 45.51 & 13.57 \\
Well & 137 & & 20.24 \\
Water contact activity & 84 & 50 & 59.52 & 25.88 \\
Bathing & 44 & 25 & 56.82 & 2.70 \\
Irrigation farming & 14 & 10 & 71.43 & 2.70 \\
Feeding animals & 8 & 6 & 75.00 & 0.00 \\
Fetching & 1 & 0 & 0.00 & 4.67 \\
Passing & 231 & 86 & 37.23 & 13.33 \\
Do not know & 18 & 15 & 83.33 & 13.77 \\
Washing & & & & 10.65 \\
Dysuria & 400 & 77 & 19.25 & 12.02 \\
Painful urination & 400 & 115 & 28.75 & 48.00 \\
No painful urination & 400 & 192 & & \\
Total & & & & \\
\hline
\end{tabular}

Borno State; Ladan et al. (2011) in Gusau, Zamfara State; Bello et al. (2014) in Sokoto State; Dawaki et al. (2016) in Kano State; and Hassan et al. (2017) in Kebbi State observed significant association of S. haematobium infection with males.

The lack of significant association of S. haematobium infection with age is an indication that regardless of age, all pupils are equally exposed to cercaria-contaminated water bodies. This agrees with the findings of Joseph et al. (2010) in Maiduguri, Borno State; Dawet et al. (2012) in Jos North, Plateau State; Kabiru et al. (2013) in Wamakko, Sokoto State; Damen et al. (2018) in North Central; and Nwachukwu et al. (2018) in Ebonyi State where they reported no significant association in the occurrence of $S$. haematobium infection with age. However, Dawaki et al. (2016) in Kano and Hassan et al. (2017) in Kebbi State reported a significant association of S. haematobium infection with age.

Although Kabiru et al. (2013) in Wamakko reported significant association in the occurrence of $S$. haematobium infection with fishing, findings of this study revealed lack of significant association in the occurrence of $S$. haematobium infection with water contact activity. This indicates that the schools examined were close to the river, hence frequent exposure of pupils to the source of $S$. haematobium infection.

The lack of significant association of S. haematobium infection with a source of drinking water shows that all pupils are equally exposed to contaminated water bodies. This agrees with the findings of Dawaki et al. (2016) in Kano. However, Dawet et al. (2012) in Jos North, Plateau
State, and Nwachukwu et al. (2018) reported a significant association of $S$. haematobium infection with a source of drinking water, as a subject who obtain their water from stream was significantly more infected than those who use well.

\section{Conclusion}

In conclusion, this study demonstrated that S. haematobium infection was prevalent among primary school pupils in Wamakko Local Government, Sokoto State, and that all pupils in the study area are equally exposed to the sources of $S$. haematobium infection. Therefore, mass chemotherapy, provision of health education to the communities, provision of safe water supply and sanitation facilities are highly advocated.

\section{Acknowledgements}

We wish to acknowledge the contribution of Wamakko Local Government Education Authority, Headmasters of the schools examined. That authors declared that there is no conflict of interest.

\section{Funding}

No funding was received during the research.

Availability of data and materials

Not applicable.

Authors' contributions

IA conceived the study and carried out the laboratory practical. AY computed and analysed the data. K and SA drafted the manuscript. IA identified the parasites recovered. All authors read and approved the final manuscript.

Ethics approval and consent to participate

The research was approved by Wamakko Local Government Education authority. Headmasters obtained informed consent from parents/guardians 
of the pupils after explaining the purpose and procedure of the study. Pupils were not forced to participate and were free to drop at any stage of the study.

\section{Consent for publication}

Not applicable.

\section{Competing interests}

The authors declare that they have no competing interests.

\section{Publisher's Note}

Springer Nature remains neutral with regard to jurisdictional claims in published maps and institutional affiliations.

\section{Author details}

'Department of Biological Sciences, Usmanu Danfodiyo University, Sokoto, Nigeria. ${ }^{2}$ Department of Biological Sciences, Federal University, Gusau, Zamfara State, Nigeria.

Received: 22 October 2018 Accepted: 1 April 2019

Published online: 25 April 2019

\section{References}

Adeyaba, O. A., \& Ojeaga, S. G. T. (2002). Urinary schistosomiasis and concomitant urinary tract pathogens among school children in metropolitan Ibadan, Nigeria. African Journal of Biomedical Research, 5, 103-107.

Akinboye, D. O., Ajisebutu, J. U., Fawole, O. M., Agbolade, O. M., Akinboye, D. O., Amosu, A. M., ... Emem, O. (2011). Urinary schistosomiasis. Water contact frequency and infertility among secondary school students in Ibadan, Nigeria. Nigerian Journal of Parasitology, 32, 129-134.

Badmos, K. B., \& Komolafe, A. O. (2007). Schistosomiasis presenting acute appendicitis. African Medical Journal, 83, 528-532.

Bello, A., Jimoh, O. A., Shiitu, S. B., \& Hudu, S. A. (2014). Prevalence of urinary schistosomiasis and associated haemato-proteinuria in Wurno Rural Area of Sokoto State, Nigeria. Orient Journal of Medicine, 26(3-40), 114-121.

Carter Center (2015). Schistosomiasis control program. Retrieved on 1 Jan 2015 http://www.cartercenter.org.

Damen, J. G., Kopkuk, E. D., \& Lugos, M. D. (2018). Prevalence of urinary schistosomiasis among irrigation farmers in North Central Nigeria. Journal of Medical and Health Sciences, 7(3), 1-4.

Dawaki, S., Al-Mekhlafi, H. M., Ithoi, I., Ibrahim, J., Abdulsalam, A. M., Ahmed, A., .. Surin, J. (2016). Prevalence and risk factors of schistosomiasis among Hausa communities in Kano State, Nigeria. Revista do Instituto de Medicina Tropical de São Paulo, 58, 54.

Dawet, A., Benjamin, C. B., \& Yakubu, D. P. (2012). Prevalence and intensity of Schistosoma haematobium among residents of Gwong and Kabong in Jos North local government area, Plateau State, Nigeria. International Journal of Tropical Medicine, 7(2), 69-73.

Guyatt, H., Brooker, S., Lwambo, N. J. S., Siza, J. E., \& Bundy, D. A. P. (1999). The performance of school-based questionnaires of reported blood in urine in diagnosing Schistosoma haematobium infection: Patterns by age and sex. Tropical Medicine \& International Health, 4(11), 751--757.

Hassan, J., Mohammed, K., Opaluwa, S. A., Adamu, T., Nataala, S. U., Garba, M. K., ... Bunza, N. M. (2017). Diagnostic potentials of haematuria and proteinuria in urinary Schistosomiasis among school-age children in Aliero Local Government Area, Kebbi State, North-Western Nigeria. Asian Journal of Research in Medical and Pharmaceutical Sciences, 2(4), 1-9.

Joseph, M. B., Gaji, B., Muhammad, I., Baba, M. M., \& Thilza, I. B. (2010). The incidence of schistosomiasis in primary school pupils with particular preference to $S$. haematobium in Maiduguri. Researcher, 2(3), 31-36.

Kabiru, M., Ikeh, E. I., Aziah, I., Julia, O., Fabiyi, J. P., \& Mohammed, R. A. (2013). Prevalence and intensity of Schistosoma haematobium infection. A community based survey among school children and adult in Wamakko town, Sokoto State, Nigeria. International Journal of Tropical Medicine and Public Health, 2(1), 12-22.

Ladan, M. U., Abubakar, U., Abdullahi, K., Bunza, M. D. A., Nasiru, M., \& Ladan, M. J. (2011). Gender and age-specific prevalence of urinary schistosomiasis in selected villages near a dam site in Gusau local government area, Zamfara State. Nigerian Journal of Parasitology, 32(1), 55-59.

Madsen, H., \& Christensen, N. Ø. (1992). Intermediate hosts of schistosomiasis: Ecology and control. Bulletin of the Society for Vector Ecology, 17, 2-9.
Mott KE, Dixon H, Osci-Tutu E, England EC, (1983). Relationship between intensity of Schistosoma haematobium infection and clinical haematuria and proteinuria. Lancet, 1: 1005-1008.

National Population Census (2015). Projected population, 2015-2020. Sokoto: National Population Commission Office.

Nwachukwu, P. C., Ohaeri, C. C., Ukpai, O. M., Irole-Eze, O. P., \& Amaechi, E. C. (2018). Prevalence of Schistosoma haematobium infection among schoolaged children in Afikpo North Local Government Area, Ebonyi State, Nigeria. Sri Lankan Journal Biology, 3(2), 1-8.

Olds GR, Srinivasan D (2000). Schistosomiasis. Current Treatment Options inlnfectious Diseases. 2:88-99.

Pugh, R. N. H. (1978). Malumfashi endemic disease research project II. Annals of Tropical Medicine and Parasitology, 73, 295.

Robson, J (2013). Schistosomiasis. Sullivan Nicolaides pty Itd. 134 Whitmore street. Taringa, QLD 4068. Australia. Pp. 1-2.

Sarkinfada, F., Azeez-Akande, O., Isa, A. S., \& Zubairu, I. (2009). Urinary schistosomiasis in the Danjarima community in Kano, Nigeria. Journal of Infections Developing Countries, 3(6), 452-457.

Sturrock, R. F. (2001). Schistosomiasis epidemiology and control: How did we get here and where should we go? Memórias do Instituto Oswaldo Cruz, 96(suppl), 17-27.

Van der Werf, M. J., de Vlas, S. J., Brooker, S., Looman, C. W., Nagel-Kerke, M. J., et al. (2003). Quantification of clinical morbidity associated with schistosome infection in subSaharan Africa. Acta tropica, 86, 125-139.

World Health Organization (2002). Prevention and control of schistosomiasis and soiltransmitted helminthiasis. WHO Technical Report Series No. 912. Geneva: World Health Organization.

World Health Organization (2012). Research priorities for helminth infections: Technical report of the TDR disease reference group on helminth infections. (Technical report series; no. 972), (pp. 60-62).

\section{Submit your manuscript to a SpringerOpen ${ }^{\circ}$ journal and benefit from:}

- Convenient online submission

- Rigorous peer review

- Open access: articles freely available online

High visibility within the field

- Retaining the copyright to your article

Submit your next manuscript at $\boldsymbol{\sim}$ springeropen.com 